\title{
35 \\ The regulation of work health and safety
}

Elizabeth Bluff

\section{Introduction}

This chapter is about regulating the harmful effects of work, which globally results in around two million deaths each year (ILO 2003). A further 270 million people suffer traumatic injuries and 160 million are affected by diseases arising from their work. Clearly, for many people, work falls short of sustaining their physical, mental and social wellbeing, as envisaged by the International Labour Organization (ILO) in its Convention Concerning Occupational Safety and Health and the Working Environment (ILO 1981).

As in other fields, in work health and safety (WHS), the concept of regulation ranges from state regulation in the form of legal obligations and public agencies that promote, monitor and enforce compliance to the wider non-state mechanisms in local, national and transnational domains that influence enterprise conduct (Black 2001). This chapter applies this broader, 'decentred' conception of regulation, together with Parker and Nielsen's (see their Chapter 13, this volume) holistic and plural model of business compliance, in examining the regulation of WHS through a series of interrelated conceptual themes, as follows (Parker and Nielsen 2011). 
Taking enterprise behaviour as the starting point, nine practices are outlined, which, if rigorously implemented, sustain better protection for health and safety at work. Enterprise behaviour is, however, motivated by business goals and priorities, and influenced by organisational capacities and characteristics. In turn, non-state institutions and actors in enterprises' social and economic environments shape their motivations and capacities, with positive or adverse consequences for WHS. After examining these issues, the chapter turns to state regulation, including WHS laws and the role of state regulators, which seek to influence motivations and capacities and, through these, actions and outcomes for WHS. While the empirical research and theory canvassed in this chapter are applicable in different countries, the challenge of regulating transnationally in the context of global supply chains warrants specific attention, and this is the focus of the final section.

\section{Enterprise behaviour: Preventive practices}

Empirical research suggests nine practices for effectively managing WHS to prevent work-related injuries, disease and deaths, as outlined by Johnstone et al. (2012). First, risk management is the central focus of WHS management as, to ensure health, safety and wellbeing, the enterprise must rigorously and comprehensively identify potential sources of harm, implement and maintain measures to eliminate or minimise risks and give preference to measures that design out or control risks at the source (see also 'Laws for WHS' below). Second, initiatives to manage WHS are led by senior managers and are planned, resourced, implemented and reviewed to ensure their effectiveness. Third, attention to WHS is integral to other organisational decision-making and functions, and forms part of the responsibilities of managers, supervisors and workers, commensurate with their roles. Fourth, WHS knowledge and skills are developed across the enterprise and are not confined to particular individuals, even if the enterprise employs or engages WHS professionals or practitioners to facilitate WHS management (see also 'Organisational capacities' below).

A fifth practice is open and constructive communication about WHS matters among managers, supervisors and workers, and active worker participation through operational meetings (staff or toolbox) or health and safety representatives and committees. Priorities for participative problem solving are risk analysis for tasks and work roles, inspections 
of the work environment and response to incidents and hazardous exposures. Sixth, monitoring and investigation of these events, and the underlying reasons for them, are crucial to minimising their impact, as are prompt first aid, access to medical treatment and emergency response. Seventh, enterprises have arrangements in place to consult, cooperate and coordinate on WHS matters with their wider workforce of contractors, subcontractors, agency and other precarious workers, as well as their suppliers, customers and end-users of their products and services (see also 'Laws for WHS' below).

The eighth practice for effective WHS management is succinct documentation, which assists the enterprise to communicate WHS arrangements internally and to demonstrate compliance with WHS legal obligations to regulators and external stakeholders. Last, independent audits enable the enterprise to evaluate the capacity of its arrangements to prevent work-related injury, disease and death, and to draw information from a cross-section of managers, supervisors and workers, documentation of arrangements and observation of work and work environments.

Practices such as these can sustain the commitment to, capacity and arrangements for an enterprise to self-regulate and comply with its legal obligations for WHS. On face value, they seem straightforward, but, in reality, many different factors and processes affect the willingness and capacity of enterprises and their workers to address WHS matters effectively. First among these are motivational factors.

\section{Goals and priorities that motivate enterprise behaviour}

As the factors that drive or energise action and behaviour, motivations play a significant role in shaping the conduct of enterprises. Socio-legal scholars have characterised enterprise motivations as legal, economic, social and normative, or a subset or amalgam of these (Kagan et al. 2011; May 2004). Legal motivations derive from the perceived authority of the law and the threat of penalties if noncompliance is detected, while economic motivations relate to regulatees' commercial goals to maximise profit. Social motivations stem from regulatees' desire to earn the approval and respect of significant people with whom they interact 
(to be seen to do the right thing) and normative motivations arise from regulatees' desire to conform to internalised norms or beliefs about right and wrong.

For WHS, empirical studies have established the contextualised and plural nature of enterprises' motivations, which may provide positive rationales for taking preventive action or negative justifications for not doing so. For example, a study of UK enterprises concluded they were motivated to address WHS if poor safety standards had the potential to threaten business survival, if there were serious and well-recognised health risks for their operations and/or if they were large and highly visible to the inspectorate or local community (Genn 1993). When none of these conditions was met, firms subordinated safety to profitability goals. Profitability was also the driving force behind Australian construction firms' responses to work-related fatalities and, while influential and large firms were able to accommodate safety, smaller firms and those prone to competitive pressures chose between profit and safety (Haines 1997).

In contrast, for Australian enterprises from a cross-section of industries, motivations included a normative sense of moral and ethical duty to provide a safe workplace, economic concerns relating to insurance, reputational concerns and the threat of prosecution and penalties (Jamieson et al. 2010). For enterprises such as machinery manufacturers, motivations derived from a mix of legal and technical standards ${ }^{1}$ and/or the economic goal of ensuring the marketability of machinery and firm profitability, and these tended to outweigh a sense of moral duty to protect human safety (Bluff 2015a).

Recognising the contextualised and plural nature of motivations goes some way towards explaining workplace actions and outcomes for WHS. It does not, however, completely account for enterprise behaviour, which is also shaped by organisational capacities and characteristics. These, like motivational factors, are highly contextualised.

1 See, for example, international (International Organization for Standardization: ISO), European (European Committee for Standardization: CEN), US (American National Standards Institute: ANSI) and Australian (Standards Australia: AS) standards. 


\section{Organisational capacities and characteristics that shape decision-making and action}

Safety and socio-legal scholarship have recognised the central role of capacity, including knowledge and skills, in enterprise self-regulation and action on WHS (Hale and Hovden 1998; Nytrö et al. 1998; Parker and Nielsen 2011). Furthermore, work itself is a significant source of WHS knowledge and skills as learning takes place through participation in work activities and interactions (Billett 2001; Brown and Duguid 1991), including through observation of others' behaviour, conversations and storytelling and questioning and problem solving (Bluff 2015b; Gherardi and Nicolini 2002; Sanne 2008). In these respects, knowledge comprises individuals' personal stocks of information, skills, experiences, beliefs and memories (Alexander 1991).

One implication of this is that opportunities to participate in sound WHS practice and problem solving, and to observe and interact with competent practitioners, foster better learning about WHS. Yet a lot of WHS information and training are not grounded in authentic work experiences, and instead attempt to 'transfer knowledge' through information materials or training (face-to-face or online). A further implication is that, as learning about WHS is situated in work activities and interactions, there are multiple bases for constructing WHS knowledge and skills, and these go beyond authoritative sources such as legal and technical standards or advice and information from WHS regulators. To the extent that enterprises do engage with WHS regulatory and professional communities of practice, this is facilitated by WHS professionals and practitioners who help to source information, promote workplace dialogue around WHS, support risk management and highlight the costs and legal consequences of not taking preventive action (Broberg and Hermund 2007; Hale et al. 2010; Jamieson et al. 2010).

Moving beyond issues of capacity, certain enterprise characteristics pose significant challenges for WHS. For example, enterprise restructuring, outsourcing, engaging workers as (sub)contractors or hired labour, conducting business in supply chains and franchising arrangements have reduced enterprises' control over work, weakened chains of responsibility, contributed to the fracturing and complexity of work 
processes and increased the proportion of workers in flexible, less secure, temporary, part-time or casual employment or working as self-employed contractors (Johnstone et al. 2012; Quinlan et al. 2010). In supply chains and franchising arrangements, there is a stark contrast between the commercially powerful enterprises at the apex of these arrangements and the often small enterprises or self-employed individuals (including outworkers) who produce and supply the goods or services under poor conditions for WHS, remuneration, hours of work, job security and access to workers' compensation and rehabilitation (Frazer et al. 2008; James et al. 2007; see also 'Laws for WHS' and 'WHS in global supply chains' below).

Enterprise size is a key characteristic influencing willingness and capacity to address WHS matters. The difficulties that smaller enterprises, and their workforces, experience in dealing with WHS matters are multifaceted, ranging from limited resources and management expertise to competitive pressures, lower positions in contracting (or franchising) hierarchies, shorter life cycles and inadequate worker representation (Lamm and Walters 2004; MacEachern et al. 2010). Moreover, effective strategies for building WHS capacity in small enterprises are resource-intensive as they require face-to-face discussions and practical problem solving for real risks facilitated by WHS advisers, as regulators or consultants (James et al.2004; Stave et al. 2008).

These are just some of the ways that organisational capacities and characteristics may impact on WHS. Diversity in these aspects contributes to differences in how, and how well, enterprises address WHS matters.

\section{Non-state institutions and actors in enterprises' social and economic environments}

From the preceding discussion of organisational arrangements and relationships it is clear that multiple external actors may influence the operations of an enterprise and, in turn, that enterprise may influence others. Also, an enterprise's interactions with external actors and the distribution of responsibilities, resources and power between them, can critically affect the enterprise's willingness and capacity to address WHS matters and comply with its legal obligations. 
In regulatory theory, the role of regulatory actors beyond the state agencies that set, monitor and enforce legal obligations is recognised in the concepts of regulatory space and decentred regulation (Black 2001; Hancher and Moran 1989). As well as enterprises' customers or clients, and parties in supply chains and franchising arrangements, other influential non-state actors for WHS include industry and professional associations, unions, insurance companies, providers of education and training, WHS consultants and technical standards bodies. In principle, these non-state actors may foster awareness of WHS and regulatory systems and positively influence WHS outcomes, but, in practice, the information they provide may be less than robust and their influence may run counter to regulatory goals or, in business relationships, they may limit a (small) enterprise's room to move on WHS (Bluff 2015a; Hutter and Jones 2007; Lamm and Walters 2004).

All of this signals the need for regulators to pay attention to the influence of non-state actors. As Haines (1997) proposes, it may be necessary to map the dynamics within, outside and between enterprises that influence their decisions and actions, as a starting point for regulation.

\section{State regulation of WHS}

\section{Laws for WHS}

Governments in developed and some developing countries have established laws aimed at protecting health and safety at work. The focus here is on these preventive WHS laws, noting, however, that levies, financial incentives and penalties, performance standards and audits under workers' compensation and rehabilitation schemes are among the wider regulatory mechanisms with government authority, which may require or encourage enterprises to improve their management of WHS (Johnstone et al. 2012; Verbeek 2010).

In framing WHS legal obligations, policymakers employ different types of standards, as described by Johnstone et al. (2012; see also Bluff and Gunningham 2004). General duties (or principles) define the obligation in terms of broad goals, while performance outcomes and performance targets, respectively, specify a required outcome or standard of exposure, as for a chemical or noise. The flexibility of these performance-based standards 
contrasts with prescriptive standards, which specify the required action and may achieve this by calling up or giving evidentiary status to detailed technical standards issued by (non-state) national and international standards bodies.

Other options are process-based standards, which, as the name suggests, set out ways to address WHS matters-for example, processes for managing WHS risks and consulting workers. In some countries, processes are combined in a systematic strategy to manage WHS, as with the European Framework Directive on measures to encourage improvements in safety and health (EC 1989). This strategy is developed more fully in requirements for 'internal control', which mandate a preventive system to plan, organise, implement and review compliance with WHS legal requirements (Saksvik et al. 2003; Walters et al. 2011; see also 'Enterprise behaviour' above). Such requirements dovetail with global developments in WHS management systems, although the latter are typically promulgated by non-state sources, ranging from large corporations to national and international standards bodies (ILO 2001; Walters et al. 2011). Complementing process and systems standards are documentation standards, which require the regulatee to record the action they take to comply - for example, documenting risk assessments, safe work methods and plans for managing WHS.

A key development in WHS policy and standard-setting is the emphasis on controlling risks at the source. One aspect of this is a focus on safe design, based on the premise that a highly effective way to protect people from harm is to eliminate or control risks at the design stage (Safe Work Australia 2012; Schulte et al. 2008). To this end, legal obligations may extend to entities that design, develop, construct or manufacture systems of work, workplaces, machinery and equipment, substances and materials. A second aspect is regulatory innovation targeting enterprises with real control and influence over WHS in supply chains for goods and services. A recent example is Australian WHS laws requiring a person conducting a business or undertaking (PCBU) to ensure, as far as reasonably practicable, the health and safety of all persons who carry out work for them, as contractors, subcontractors, hired (agency) labour, outworkers or otherwise. And, from the top to the bottom of a supply chain, each PCBU must discharge their obligations to the extent that they have the capacity to influence and control particular WHS matters (Johnstone et al. 2012: 306-10, 470-1). There are also separate chain of responsibility laws aimed at ensuring minimum industrial and WHS 
standards for workers in textile, clothing and footwear, long-haul truck transportation and cash-in-transit supply chains (Johnstone et al. 2012: 471-7; Rawling and Howe 2013).

As well as requiring enterprises to establish, implement and monitor arrangements to address WHS matters, laws for WHS constitute arrangements for their administration and enforcement. That is, they couple self-regulation with inspection and enforcement by the state in a form of enforced self-regulation (Ayres and Braithwaite 1992).

\section{The role of state WHS regulators}

The preventive WHS laws provide for external support, inspection and enforcement by state regulators, who may utilise a variety of different approaches and mechanisms to foster willingness and capacity to comply with WHS laws (Bluff 2011: 32-54; Johnstone et al. 2012: 101-6). They may raise awareness and provide information through their websites, advisory services, workshops and forums, as well as the general and social media. In their direct interactions with regulatees, they may adopt a cooperative approach (also called an accommodative, facilitative or compliance approach) in which they preference advice and persuasion as means to elicit compliance. They may be more insistent by setting out clear expectations and signalling the need for a prompt response-for example, by issuing a notice requiring action to remove or control hazards. Or, they may apply a coercive approach (also called a sanctioning or deterrence approach), which involves some form of sanction, such as issuing an infringement notice or on-the-spot fine, or pursuing prosecution and court-imposed sanctions. As provided for in the relevant WHS laws, the types of sanctions imposed by courts may include fines, jail sentences, injunctions, undertakings or different types of orders, which can impact on economic motivations and reputational concerns, as well as requiring enterprises to address weaknesses in their capacity and arrangements to comply with the law (Gunningham and Johnstone 1999: 256-8).

The strongest evidence that inspection improves WHS performance comes from the United States, where a series of studies conducted over several decades demonstrates that inspected firms have improved performance for risk control or reduced work-related injuries, illnesses or workers' compensation claims, as measured for the particular study (see for example, Baggs et al. 2003; Gray and Scholz 1993; Mendeloff 
and Gray 2005; Weil 2001). There is also evidence of prosecuted enterprises implementing additional actions to manage risks (specific deterrence), but less evidence that prosecution of others prompts nonprosecuted enterprises to take appropriate preventive action (general deterrence), as communication of information about cases may be unreliable or differences in business operations may make comparisons difficult (Jamieson et al. 2010; Schofield et al. 2009; Bluff 2015a; Thornton et al. 2005).

While there is some evidence that different types of enforcement can encourage improvements in WHS performance, there are many unanswered questions about how WHS regulators can most effectively employ the array of mechanisms and approaches available to them. For example, should WHS regulators apply risk-based regulation, deploying their regulatory resources and determining how to respond to noncompliance based on assessments of risk (Black 2010)? Should they implement some of the types of regulatory responsiveness that fall under the approach of responsive regulation (see John Braithwaite, Chapter 7, this volume), using a judicious mix of cooperative mechanisms to build capacity to comply, but, when necessary, applying more insistent and deterrent mechanisms to address persistent noncompliance (Braithwaite 2011)? If they employ responsive regulation, what should trigger an escalation in their response? Is it a regulatee's uncooperative attitude and behaviour, the gravity, frequency or seriousness of noncompliance or something else (Nielsen 2006)? And, if regulators encounter resistance from regulatees, should they move to sanctions or, as motivational posturing theory suggests (see Braithwaite, Chapter 2, this volume), should they put more effort into building trust, respect and shared understandings with these regulatees (Braithwaite 2009)?

A further issue is what constitutes 'compliance'. Is it self-regulation in the sense of willingness, capacity and arrangements to sustain ongoing preventive action and/or is it substantive compliance with regulatory goals such as eliminating or effectively minimising risks (Walters et al. 2011: 8-9, 152-5, 194-5; Parker 2002: ix-x, 27, 43-61)? And, whether the focus is self-regulation or substantive compliance, is it helpful to conceive WHS regulation as an interaction between the regulator and a single enterprise or are their benefits in networked interventions whereby regulators engage with a cross-section of enterprises operating within 
the same markets, supply chains or industry sectors ${ }^{2}$ and the industry, union, professional, insurance, training and other bodies with whom they, and their workers, interact (Bluff et al. 2012; Gunningham et al. 1998; see Gunningham and Sinclair, Chapter 8, this volume)?

These are all live debates in WHS regulation. While regulatory theory and empirical research in other fields of regulation suggest promising directions, the diversity of enterprises, the risks arising from their operations and the persuasive influence of non-state institutions and actors demand careful consideration of 'what works' for WHS regulation, how, why and in what contexts. We also need to better understand how enterprise characteristics and capacities, motivations and operating contexts influence their actions and behaviour for WHS, and how regulators can take these variables into consideration in designing and implementing their interventions. We need to better define the types of knowledge and skills that inspectors require to elicit improvements in WHS performance, which is likely to be a mix of WHS knowhow and communication and relational skills, to build rapport and cooperation with regulatees and their stakeholders.

\section{WHS regulation in global supply chains}

A very great challenge for WHS is regulation in the context of global supply chains, where corporations conduct production, extraction, transportation or other operations in developing countries. State regulation in these countries is often absent or too weak to provide meaningful protection for WHS, and work conducted there is beyond the reach of developed countries' laws, such as Australian chain of responsibility obligations (see 'Laws for WHS').

There are, however, a number of international institutions and actors in the transnational regulatory space for WHS. Key among these is the ILO, which promulgates conventions and supports the development of WHS programs at regional, national and local levels (Rosenstock et al. 2006). Others are global industry associations and corporations, international standards bodies, insurance companies, global unions, non-governmental organisations (NGOs) and social movements.

2 For example, those that design/develop, construct/manufacture, import/supply/deliver and purchase particular types of products and services within the same markets. 
For example, corporations may develop codes of conduct, the success of which depends on them having the self-interest to ensure compliance by their suppliers (Kolk and van Tulder 2005). For their part, global unions have negotiated international framework agreements with more than 100 corporations, which apply to their operations throughout the world (Global Unions n.d.). Trade development NGOs such as Fairtrade International have set standards (drawing on ILO conventions and national legislation) and support their implementation in around 70 producer countries, with inspection and certification (by FLOCERT) of supply chain participants from point of production to point of sale (Dragusanu et al. 2014). FairWear campaigns have similarly sought to improve working conditions, but through ethical networks of union and social movement participants (Burchielli et al. 2004).

The above examples highlight the different participants in emerging, hybrid forms of global labour governance, which bring together state and non-state bodies to secure action on WHS and other labour standards issues (Marginson and Meardi 2014). A significant example is the legally binding Accord on Fire and Building Safety in Bangladesh, negotiated in response to the collapse of the Rana complex, in which more than 1,100 people died and 2,500 were injured. Participants in this networked governance are the 190 apparel corporations from 20 countries that have signed up to the accord, two global unions and numerous Bangladeshi ones, four campaign and advocacy organisations and the ILO as the independent chair for the accord. Among other matters, the accord requires thorough and credible safety inspections by skilled personnel and commitments by customer companies to ensure their supplier factories implement required corrective actions.

The indications are that, globally, as within nations, no single source of state or non-state regulation is adequate to ensure continuing and effective action on WHS. Rather, successful strategies harness a combination of participants and regulatory mechanisms, including empowering non-state actors as surrogate regulators (see Gunningham and Sinclair, Chapter 8, this volume). 


\section{Conclusion}

This chapter began with some grim statistics about the prevalence of work-related deaths, injuries and diseases. While WHS laws and regulators are central players in efforts to reduce this toll, much more is at stake in determining whether enterprises are willing and able to effectively protect their workforces. Understanding the contextualised and plural nature of regulatees' motivations, the situated nature of learning about WHS and the influence of non-state institutions and actors is essential to explaining enterprise actions and outcomes for WHS. Also influential are organisational characteristics and relationships that lessen the potential for sound learning about WHS and compound nonstate regulation of work.

A necessary starting point for improving WHS performance is to understand how these 'variables' play out in particular industry, sector and enterprise domains, whether these are national, regional or transnational in scope. The optimal mix of regulatory mechanisms and approaches for improving WHS will be the one that reinforces the positive influences and tackles the negative impacts in particular circumstances and contexts. And all of this requires careful planning and strategic choices, grounded in comprehensive information and analysis, in designing and implementing regulatory interventions.

\section{Further reading}

Johnstone, R and Tooma, M 2012. Work Health and Safety Regulation in Australia: The Model Act. Sydney: The Federation Press.

Lee, S and McCann, D 2011. Regulating for Decent Work: New Directions in Labour Market Regulation. Geneva: International Labour Office. doi.org/10.1057/9780230307834.

Quinlan, M 2015. Ten Pathways to Death and Disaster: Learning from Fatal Incidents in Mines and Other High Hazard Workplaces. Sydney: The Federation Press. 


\section{References}

Alexander, P 1991. 'Coming to terms: How researchers in learning and literacy talk about knowledge', Review of Educational Research 61(3): 315-43. doi.org/10.3102/00346543061003315.

Ayres, I and Braithwaite, J 1992. Responsive Regulation: Transcending the Deregulation Debate. Oxford: Oxford University Press.

Baggs, J, Silverstein, B and Foley, M 2003. 'Workplace health and safety regulations: Impact of enforcement and consultation on workers' compensation claims rates in Washington state', American Journal of Industrial Medicine 43(5): 483-94. doi.org/10.1002/ajim.10209.

Billett, S 2001. 'Knowing in practice: Re-conceptualising vocational expertise', Learning and Instruction 11(6): 431-52. doi.org/10.1016/ S0959-4752(00)00040-2.

Black, J 2001. 'Decentring regulation: Understanding the role of regulation and self-regulation in a "post-regulatory" world', Current Legal Problems 54(1): 103-46. doi.org/10.1093/clp/54.1.103.

Black, J 2010. 'Risk-based regulation: Choices, practices and lessons learnt', in Organisation for Economic Co-operation and Development (ed.), Risk and Regulatory Policy: Improving the Governance of Risk. Paris: OECD, pp. 185-224. doi.org/10.1787/9789264082939-11-en.

Bluff, E 2011. Something to Think About: Motivations, Attitudes, Perceptions and Skills in Work Health and Safety. Canberra: Safe Work Australia. Available at: safeworkaustralia.gov.au/sites/SWA/about/ Publications/Documents/604/Something_to_think_about.pdf.

Bluff, E 2015a. Safe Design and Construction of Machinery: Regulation, Practice and Performance. Farnham, UK: Ashgate.

Bluff, E 2015b. 'Safety in machinery design and construction: Knowledge and performance', Safety Science 74(2015): 59-69. doi.org/10.1016/j. ssci.2014.10.011.

Bluff, E, Johnstone, R, McNamara, M and Quinlan, M 2012. 'Enforcing upstream: Australian health and safety inspectors and upstream duty holders', Australian Journal of Labour Law 25(1): $23-42$. 
Bluff, L and Gunningham, N 2004. 'Principle, process, performance or what? New approaches to OHS standards setting', in L Bluff, $\mathrm{N}$ Gunningham and R Johnstone (eds), OHS Regulation for a Changing World of Work. Sydney: The Federation Press, pp. 12-42.

Braithwaite, J 2011. 'The essence of responsive regulation', University of British Columbia Law Review 44(3): 475-520.

Braithwaite, V 2009. Defance in Taxation and Governance: Resistance and Dismissing Authority in a Democracy. Cheltenham, UK: Edward Elgar. doi.org/10.4337/9781848449077.

Broberg, O and Hermund, I 2007. 'The OHS consultant as a facilitator of learning in workplace design processes: Four explorative case studies in current practice', International Journal of Industrial Ergonomics 37(9): 810-16. doi.org/10.1016/j.ergon.2007.07.007.

Brown, JS and Duguid, P 1991. 'Organizational learning and communities-of-practice: Toward a unified view of working, learning and innovation', Organization Science 2(1): 40-57. doi.org/ 10.1287/orsc.2.1.40.

Burchielli, R, Delaney, A, Tate, J and Coventry, K 2004. 'The FairWear campaign: An ethical network in the Australian garment industry', Journal of Business Ethics 90(Supp. 4): 575-88. doi.org/10.1007/ s10551-010-0593-z.

Dragusanu, R, Giovannucci, D and Nunn, N 2014. 'The economics of fair trade', Journal of Economic Perspectives 28(3): 217-36. doi.org/ 10.1257/jep.28.3.217.

European Commission (EC) 1989. 'Council Directive 89/391/EEC of 12 June 1989 on the introduction of measures to encourage improvements in the safety and health of workers at work', Official Journal of the European Communities L183/32: 1-8.

Frazer, L, Weaven, S and Wright, O 2008. Franchising Australia 2008: Survey. Brisbane: Griffith University.

Genn, H 1993. 'Business responses to the regulation of health and safety in England', Law and Policy 15(3): 219-33. doi. org/10.1111/j.1467-9930.1993.tb00104.x. 
Gherardi, S and Nicolini, D 2002.'Learning the trade: A culture of safety in practice', Organization 9(2): 191-223. doi.org/10.1177/13505084 02009002264 .

Global Unions n.d. Framework Agreements. Brussels: Global Unions. Available at: global-unions.org/+-framework-agreements-+.html.

Gray, W and Scholz, J 1993. 'Does regulatory enforcement work? A panel analysis of OSHA enforcement', Law Society Review 27: 177-213. doi.org/10.2307/3053754.

Gunningham, N and Johnstone, R 1999. Regulating Workplace Safety: Systems and Sanctions. Oxford: Oxford University Press.

Gunningham, N, Grabosky, P and Sinclair, D 1998. Smart Regulation: Designing Environmental Policy. Oxford: Clarendon Press.

Haines, F 1997. Corporate Regulation: Beyond 'Punish or Persuade'. Oxford: Clarendon Press.

Hale, A and Hovden, J 1998. 'Management and culture: The third age of safety. A review of approaches to organisational aspects of safety, health and environment', in AM Feyer and A Williamson (eds), Occupational Injury: Risk, Prevention and Intervention. London: Taylor \& Francis, pp. 129-65. doi.org/10.1201/9780203212493. ch11.

Hale, A, Guldenmund, F, van Loenhout, P and Oh, J 2010. 'Evaluating safety management and culture interventions to improve safety: Effective intervention strategies', Safety Science 48(8): 1026-35. doi.org/10.1016/j.ssci.2009.05.006.

Hancher, L and Moran, M 1989. Capitalism, Culture and Regulation. Oxford: Clarendon Press.

Hutter, B and Jones, C 2007. 'From government to governance: External influences on business risk management', Regulation and Governance 1(1): 27-45. doi.org/10.1111/j.1748-5991.2007.00004.x.

International Labour Organization (ILO) 1981. Convention Concerning Occupational Safety and Health and the Working Environment. No.155. Geneva: International Labour Organization. 
International Labour Organization (ILO) 2001. Guidelines on Occupational Safety and Health Management Systems. Geneva: International Labour Organization.

International Labour Organization (ILO) 2003. Safety in Numbers. Geneva: International Labour Organization.

James, P, Johnstone, R, Quinlan, M and Walters, D 2007. 'Regulating supply chains to improve health and safety', Industrial Law Journal 36(2): 163-87. doi.org/10.1093/indlaw/dwm002.

James, P, Vickers, I, Smallbone, D and Baldock, R 2004. 'The use of external sources of health and safety information and advice: The case of small firms', Policy and Practice in Health and Safety 2(1): 91-103. doi.org/10.1080/14774003.2004.11667645.

Jamieson, S, Reeve, B, Schofield, T and McCallum, R 2010. 'OHS prosecutions: Do they deter other companies from offending?', Journal of Occupational Health, Safety and Environment 26(3): 213-31.

Johnstone, R, Bluff, E and Clayton, A 2012. Work Health and Safety Law and Policy. Sydney: Thomson Reuters.

Kagan, R, Gunningham, N and Thornton, D 2011. 'Fear, duty, and regulatory compliance: Lessons from three research projects', in C Parker and VL Nielsen (eds), Explaining Compliance: Business Responses to Regulation. Cheltenham, UK: Edward Elgar, pp. 37-58. doi.org/10.4337/9780857938732.00007.

Kolk, A and Van Tulder, R 2005. 'Setting new global rules? TNCs and codes of conduct', Transnational Corporations 14(3): 1-27.

Lamm, F and Walters, D 2004. 'Regulating occupational health and safety in small business', in E Bluff, N Gunningham and R Johnstone (eds), OHS Regulation for a Changing World of Work. Sydney: The Federation Press, pp. 94-119.

MacEachern, E, Kosny, A, Scott-Dixon, K, Facey, M, Chambers, L, Breslin, C, Kyle, N, Irvin, E and Mahood, Q 2010. 'Workplace health understandings and processes in small businesses: A systematic review of the qualitative literature', Journal of Occupational Rehabilitation 20(2): 180-98. doi.org/10.1007/s10926-009-9227-7. 
Marginson, P and Meardi, G 2014. 'Global labour governance: An idea whose time has come', IRRU Briefing 23: 1-3.

May, P 2004. 'Compliance motivations: Affirmative and negative bases', Law and Society Review 38(1): 41-68. doi.org/10.1111/j.00239216.2004.03801002.x.

Mendeloff, J and Gray, W 2005. 'Inside the black box: How do OSHA inspections lead to reductions in workplace injuries?', Law and Policy 27(2): 219-37. doi.org/10.1111/j.1467-9930.2005.00198.x.

Nielsen, VL 2006. 'Are regulators responsive?', Law and Policy 28(3): 395-416. doi.org/10.1111/j.1467-9930.2006.00232.x.

Nytrö, K, Saksvik, PO and Torvatn, K 1998. 'Organisational prerequisites for the implementation of systematic health, environment and safety work in enterprises', Safety Science 30(3): 297-307. doi.org/ 10.1016/S0925-7535(98)00050-2.

Parker, C 2002. The Open Corporation: Effective Self-regulation and Democracy. Cambridge: Cambridge University Press. doi. org/10.1017/CBO9780511550034.

Parker, C and Nielsen, VL (eds) 2011. Explaining Compliance: Business Responses to Regulation. Cheltenham, UK: Edward Elgar.

Quinlan, M, Bohle, P and Lamm, F 2010. Managing Occupational Health and Safety: A Multidisciplinary Approach. 3rd edn. Melbourne: Palgrave Macmillan.

Rawling, M and Howe, J 2013. 'The regulation of supply chains: An Australian contribution to cross-national legal learning', in K Stone and H Arthurs (eds), Retbinking Workplace Regulation: Beyond the Standard Contract of Employment. New York: Russell Sage Foundation, pp. 233-52.

Rosenstock, L, Cullen, M and Fingerhut, M 2006. 'Occupational health', in D Jamison, J Breman, A Measham, G Alleyne, M Claeson, D Evans, P Jha, A Mills and O Musgrove (eds), Disease Control Priorities in Developing Countries. 2nd edn. Washington, DC: The World Bank, pp. 1127-45. 
Safe Work Australia 2012. Australian Work Health and Safety Strategy 2012-2022. Canberra: Safe Work Australia. Available at: safeworkaustralia.gov.au/sites/swa/about/publications/pages/ australian-work-health-and-safety-strategy-2012-2022.

Saksvik, P,Torvatn, H and Nytrö, K 2003.'Systematic occupational health and safety work in Norway: A decade of implementation', Safety Science 41(9): 721-38. doi.org/10.1016/S0925-7535(02)00020-6.

Sanne, J 2008. 'Incident reporting or storytelling? Competing schemes in a safety-critical and hazardous work setting', Safety Science 46(8): 1205-22. doi.org/10.1016/j.ssci.2007.06.024.

Schofield, T, Reeve, B and McCallum, R 2009. 'Deterrence and OHS prosecutions: Prosecuted employers' responses', Journal of Occupational Health and Safety - Australia and New Zealand 25(4): 263-76.

Schulte, P, Rinehart, R, Okun, A, Geraci, CL and Heidel, DS 2008. 'National Prevention through Design (Ptd) initiative', Journal of Safety Research 39(2): 115-21. doi.org/10.1016/j.jsr.2008.02.021.

Stave, C,Pousette, A and Törner,M 2008.'Risk and safety communication in small enterprises: How to support a lasting change towards work safety priority', Journal of Risk Research 11(1-2): 195-206. doi. org/10.1080/13669870701875875.

Thornton, N, Gunningham, N and Kagan, R 2005. 'General deterrence and corporate environmental behaviour', Law and Policy 27(2): 262-88. doi.org/10.1111/j.1467-9930.2005.00200.x.

Verbeek, J 2010. 'How do we know if monetary incentives are effective and efficient for controlling health and safety risks at work?', Scandinavian Journal of Work Environment and Health 36(4): 269-71. doi.org/10.5271/sjweh.3032.

Walters, D, Johnstone, R, Frick, K, Quinlan, M, Baril-Gingras, G and Thébaud-Mony, A 2011. Regulating Workplace Risks: A Comparative Study of Inspection Regimes in Times of Change. Cheltenham, UK: Edward Elgar. doi.org/10.4337/9780857931658.

Weil, D 2001. 'Assessing OSHA performance: New evidence from the construction industry', Journal of Policy Analysis and Management 20(4): 651-74. doi.org/10.1002/pam.1022. 
This text is taken from Regulatory Theory: Foundations and applications, edited by Peter Drahos, published 2017 by ANU Press, The Australian National University, Canberra, Australia. 